\title{
Osler Centenary Papers: Equanimity 2020
}

\author{
John Launer
}

William Osler wrote more than a dozen books and over 750 articles in his lifetime, but one book and one article are by far the best known. 'Principles and Practice of Medicine' was published in 1892 and was a huge success. It went through 17 editions and established a model for textbooks of general medicine to the present day. The enduring fame of his short piece entitled 'Aequanimitas', 1 composed 3 years earlier, might have surprised him more. It was the transcript of an address he gave to new medical graduates at the University of Pennsylvania. It also served as his farewell lecture before he departed to become chief of staff at Johns Hopkins Hospital.

Reading it now, it seems in some ways very much from a bygone age. Osler assumes, for example, that every member of his audience will have a comfortable familiarity with classical literature, the Bible and Shakespeare. The first paragraph alone contains at least five references to the classics, including the tale of Er the Pamphylian from Plato's Republic. Later, he reminds his audience that the word 'aequanimitas' ('equanimity') was used by the benign Roman emperor Antoninus Pius on his deathbed, as his choice of the day's military password. He would have taken it for granted that all his students knew the word meant 'calmness of soul', from the Latin words 'aequus' and 'animus'. It is not a style that would appeal to many new medical graduates today.

The first three pages do not mention equanimity at all but cover a related quality, imperturbability. His approach is striking because of his insistence that imperturbability is largely a physical endowment, or in other words genetic. According to Osler, you either have it or you do not. If not, you may have to 'educate your nerve centres' to prevent vasomotor changes in your face, for example, betraying emotions such as doubt or embarrassment. Even then, your success may still be limited. Listening to this, a modern faculty might shift uncomfortably in their seats, concerned at how graduates without the right genetic endowment might be feeling, or hoping that he will mention the importance of displaying empathy. He does not.

Correspondence to Dr John Launer, Associate Editor, Postgraduate Medical Journal, London WC1H 9JP, UK; johnlauner@aol.com

From every account, Osler was a kind and generous man, capable of deep emotion, ${ }^{2}$ so it would be a mistake to believe he was suggesting that doctors should deny their feelings. Rather, he was advising them to assume certain a kind of bodily performance. He acknowledged that some patients might misinterpret this as hardness, but argued that 'a callousness which thinks only of the good to be effected, and goes ahead regardless of smaller considerations, is the preferable quality'. In his own time, this certainly fitted with the expectations of his profession, class, gender, and culture, just much as an ability to cite the classics. Many patients might now find a performance of Oslerian imperturbability not only harsh but pompous and artificial, but as Terence Ryan points out in this issue, time changes people's perspectives. ${ }^{3}$ Later on in this article, I speculate on how Osler might update the concept of imperturbability.

\section{OBSTACLES TO EQUANIMITY}

As described by Osler, equanimity is a 'mental equivalent' to imperturbability. What he means by this is close to the philosophy of stoicism, and indeed the published version of the talk is prefaced by a quotation from the Roman emperor and Stoic philosopher Marcus Aurelius. Osler addresses equanimity mainly by describing four obstacles that his audience will face as they enter their careers and try to sustain this quality. The first obstacle is the credulity of ordinary citizens-for example, in relation to their use of ineffective patent medicines. Osler advises his graduates 'not to expect too much of the people among whom you dwell' but to reflect instead on their own 'little foibles' as doctors, and the similarity of their weaknesses to everyone else's. The next obstacle he mentions is the 'uncertainty which pertains not only to our science and art but to the very hopes and fears which make us men'. It is noticeable that the scope of uncertainty he is referring to here covers not just anxiety about clinical work, but existential doubts.

The remaining two obstacles are counterposed against each other. Osler wants to caution his audience that 'for some of you, there is in store disappointment, perhaps failure'. Before doing so, however, he warns his students and their faculty of the equal dangers of having 'a large and successful practice'. This will expose them to the risk of 'laying waste their powers', with the result that 'there is no place in your habit-stricken souls for those gentle influences which make life worth living'.

In contrast to the passage on imperturbability, it takes little imagination to transpose Osler's comments on equanimity into the 21 st century. Which of us does not know a doctor who is impatient with lay beliefs, unaware of their own shortcomings, consumed with anxiety by challenging cases or life events, seduced by success or haunted by the risk of failure? Which of us has not at some time been in such places ourselves? Possibly we might prefer to use other language for some of his words: self-awareness instead of 'little foibles' and workaholism and burnout rather than 'habit-stricken souls'(although other terms like uncertainty and professional failure have not dated at all). Either way, we might still wonder whether any contemporary physician or educator would dare to spell out all these obstacles as directly or compassionately as Osler did.

\section{BEYOND IMPERTURBABILITY}

Like many speakers on these occasions, Osler reassured everyone at the start of his talk that it would not be a very long one, and he would consider only 'two of the score of elements which may make or mar your lives'. So it is worth speculating which others he might have wanted to include apart from imperturbability and equanimity, or what he would select if he were alive today. Kindness would probably have been among them. But changed times require new concepts, and I imagine he would now consider replacing imperturbability with a more updated concept, sensitive to the different relationships that today's doctors have with their patients. If so, the concept I hope he might choose in its place is 'reflexivity.'

Reflexivity is often discussed in psychology and has now begun to have a significant impact in medicine and medical education. ${ }^{45}$ It is sometimes referred to as 'taking a helicopter view' of your encounters or becoming an 'observer-participant' in every aspect of your professional life. It refers to the capacity to examine your own feelings, reactions and motives, along with how these are influencing your actions and speech at any particular moment. A crucial element of reflexivity is asking questions like: 'why am I choosing to say these words to this person at this moment, and what effect is it having?' An 


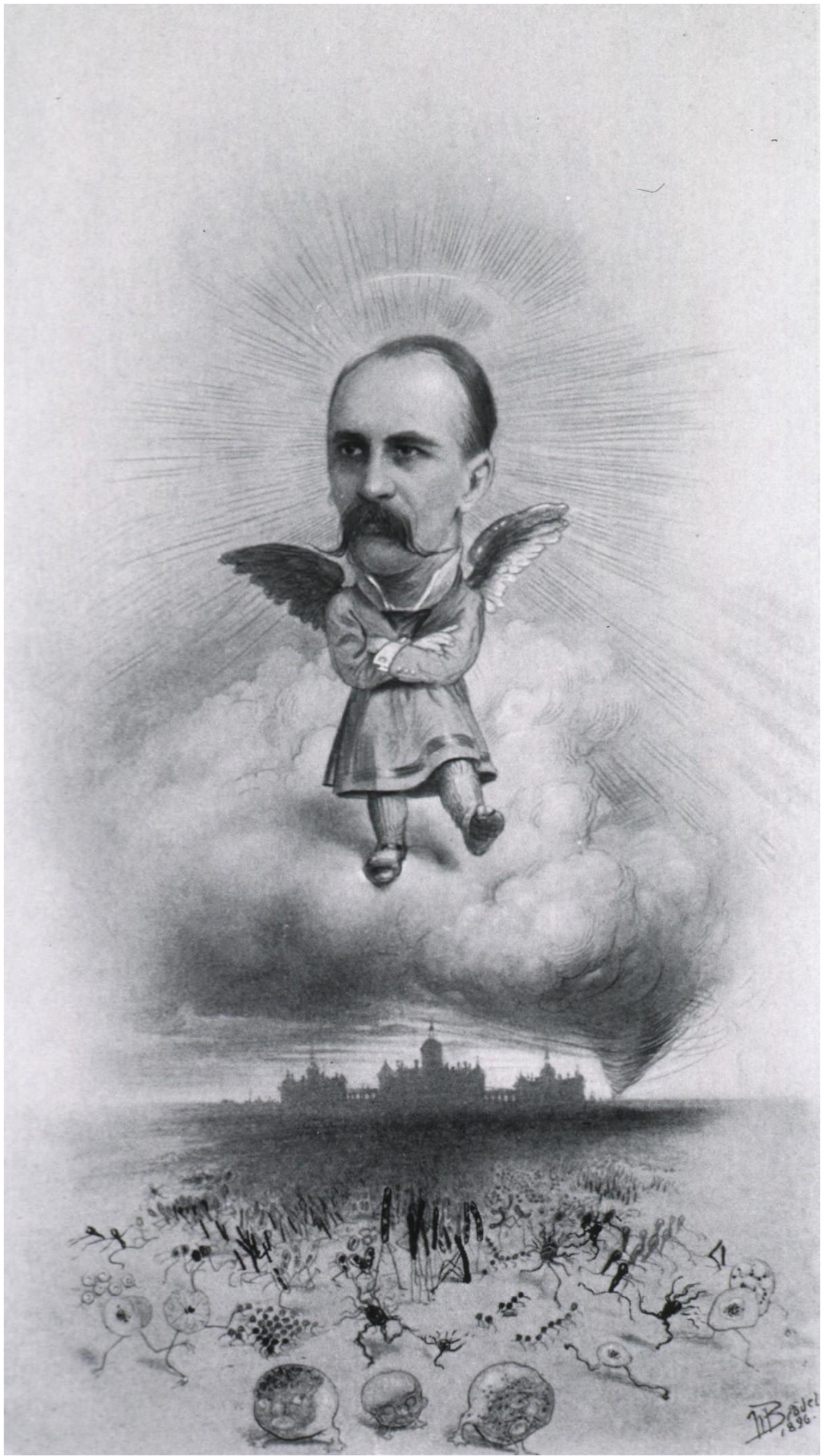

Figure 1 Cartoon of Osler. Credit: Osler Library of the History of Medicine, McGill University. William Osler Photo Collection/NLM/NIH 
equally important element is to calibrate your utterances and actions continually in response to what you observe.

In some ways reflexivity is similar to imperturbability, because it depends on managing your own behaviour and consciously adjusting your performance accordingly. The main difference is that it involves drawing on a wide repertoire of different styles of performance, as necessary. For example, it might be entirely right to display a calm and measured manner with one patient, but more beneficial to allow oneself to become animated and expansive with someone else, or even with the same person at another time. Given the range of working contexts for many doctors now, the variety of human beings we each encounter, and the differences in their expectations, we may need to behave like William Osler at one instant but a TV celebrity doctor the next-or anyone in between.
As all the articles in this themed edition show, Osler was a man ahead of his time in many ways, a leader who constantly moved forward and brought others along with him. I expect that he would have grasped the idea of reflexivity with as much openness and enthusiasm as he brought to all his endeavours. Looking down on us now benignly from above (see figure 1), he might also have offered a suitable biblical quotation in support of this. Perhaps, it would have been 'For wisdom is better than rubies; and all the things that may be desired are not to be compared with it'. 6

Funding The authors have not declared a specific grant for this research from any funding agency in the public, commercial or not-for-profit sectors.

Competing interests None declared.

Patient consent for publication Not required.

Provenance and peer review Not commissioned; internally peer reviewed. (c) Author(s) (or their employer(s)) 2019. No commercial re-use. See rights and permissions. Published by BMJ.

$$
\text { Check for updates }
$$

To cite Launer J. Postgrad Med J 2019;95:682-684.

Postgrad Med J 2019;95:682-684.

doi:10.1136/postgradmedj-2019-137115

\section{REFERENCES}

1 Osler W. Aequanimitas: with other addresses to medical students, nurses and practitioners of medicine. Philadelphia PA: P Blakiston's Son \& Co, 1904. https:// medicalarchives.jhmi.edu:8443/osler/aequessay.htm

2 Bliss M. William Osler: a life in medicine. Oxford University Press: Oxford, 1999.

3 Ryan T. Osler the clinician and scientist: a personal and historical perspective. Postgrad Med J 2019;95:600-3.

4 Baarts C, Tulinius C, Reventlow S. Reflexivity--a strategy for a patient-centred approach in general practice. Fam Pract 2000;17:430-4.

5 ledema R. Creating safety by strengthening clinicians' capacity for reflexivity. BMJ Qual Saf 2011;20:i83-6.

6 Holy Bible. Book of Proverbs; chapter 8: verse 11. 